\title{
Dynamic Analysis of the Temperature and the Concentration Profiles of an Industrial Rotary Kiln Used in Clinker Production
}

\author{
DIULIA C.Q. RODRIGUES ${ }^{1}$, ATÍLIO P. SOARES JUNIOR ${ }^{2}$ ESLY \\ F. COSTA JUNIOR ${ }^{3}$ and ANDRÉA O.S. COSTA ${ }^{3}$ \\ ${ }^{1}$ Programa de Engenharia Química, Universidade Federal do Espírito Santo/ UFES/ CCA, Campus de \\ Alegre, Alto Universitário, s/n, Guararema, Caixa Postal 16, 29500-000 Alegre, ES, Brazil \\ ${ }^{2}$ Fábrica de Cimento Nassau, Bairro Monte Líbano, 29300-970 Cachoeiro de Itapemirim, ES, Brazil \\ ${ }^{3}$ Departamento de Engenharia Química, Escola de Engenharia, Universidade Federal de Minas \\ Gerais, Avenida Antônio Carlos, 6627, 31270-901 Belo Horizonte, MG, Brazil
}

Manuscript received on September 30, 2016; accepted for publication on August 24, 2017

\begin{abstract}
Cement is one of the most used building materials in the world. The process of cement production involves numerous and complex reactions that occur under different temperatures. Thus, there is great interest in the optimization of cement manufacturing. Clinker production is one of the main steps of cement production and it occurs inside the kiln. In this paper, the dry process of clinker production is analysed in a rotary kiln that operates in counter flow. The main phenomena involved in clinker production is as follows: free residual water evaporation of raw material, decomposition of magnesium carbonate, decarbonation, formation of $\mathrm{C}_{3} \mathrm{~A}$ and $\mathrm{C}_{4} \mathrm{AF}$, formation of dicalcium silicate, and formation of tricalcium silicate. The main objective of this study was to propose a mathematical model that realistically describes the temperature profile and the concentration of clinker components in a real rotary kiln. In addition, the influence of different speeds of inlet gas and solids in the system was analysed. The mathematical model is composed of partial differential equations. The model was implemented in Mathcad (available at CCA/UFES) and solved using industrial input data. The proposal model is satisfactory to describe the temperature and concentration profiles of a real rotary kiln.
\end{abstract}

Key words: Clinker, dynamic analysis, mathematical modelling, rotary kiln.

\section{INTRODUCTION}

Some of the challenges facing the cement industries are the high energy demand of production, the continuous increase in fuel prices, process complexity and environmental impact (Atmaca and Yumruta 2014, Tsamatsoulis 2014, Kaddatz et

Correspondence to: Diulia Caroline Quites Rodrigues

E-mail: diulaicaroline@hotmail.com al. 2013, Gartner and Macphee 2011, Schneider et al. 2011, Mujumdara et al. 2007). To address these challenges, there is great interest in optimising the cement production process (Copertaro et al. 2015, Utlu et al. 2006).

The best-known type of cement is called Portland cement, which is defined as a hydraulic cluster that is basically obtained by grinding a mixture of clinker and gypsum (Copertaro et 
al. 2015). Thus, one of the main steps of the process for obtaining cement is the synthesis of the clinker (Atsonios et al. 2015, Saidur et al. 2011). Synthesis occurs inside the rotary kiln and involves complex physical (phase changes) and chemical (endothermic and exothermic reactions) processes (Lourenço et al. 2013, Saidur 2011, Silva 2007, Boateng and Barr 1996). The main clinker components are $\mathrm{C}_{3} \mathrm{~S}\left(3 \mathrm{CaO} . \mathrm{SiO}_{2}\right), \mathrm{C}_{2} \mathrm{~S}(2 \mathrm{CaO}$. $\left.\mathrm{SiO}_{2}\right), \mathrm{C}_{3} \mathrm{~A}\left(3 \mathrm{CaO} \cdot \mathrm{AlO}_{3}\right)$ and $\mathrm{C}_{4} \mathrm{AF}\left(4 \mathrm{CaO} \cdot \mathrm{Al}_{2} \mathrm{O}_{3}\right.$. $\mathrm{Fe}_{2} \mathrm{O}_{3}$ ). The intermediate reactions for obtaining the clinker and their respective heats of reaction are shown in Table I, and the temperature ranges of the formation of chemicals are shown in Table II.

Clinker production can be performed in a dry or wet process (Paula 2009). On one hand, in the dry process, the mixture of agglomerates and aggregates are completely dried and ground to feed the kiln in powder form. On the other hand, in the wet process, the mixture is a mud that is fed into the kiln with approximately $30-40 \%$ of moisture (Saidur et al. 2011, Del Coz Díaz et al. 2002). This paper considers the dry clinker production, which is the most used process in Brazilian production of cement (Kihara and Visedo 2014).

A rotary kiln in a dry cement production can be divided into five zones (Stadler et al. 2011): heating zone, calcining zone, transition zone, firing zone and cooling zone. The position of the zones along the kiln depends on the temperature and the chemical reactions being performed in the solid (Spang 1972). The temperature profile along the rotary kiln is generally not directly measured due to the scarcity of sensors that supports its

TABLE I

Chemical reactions of the clinker production process (Paula 2009, Smith 2007).

\begin{tabular}{|c|c|c|}
\hline Clinkerisation step & Chemical Reaction & $\begin{array}{l}\text { Reaction heat } \\
(\mathrm{kJ} / \mathrm{kg})\end{array}$ \\
\hline $\begin{array}{l}\text { Evaporation of residual free water and } \\
\text { water as a result of the clay combination }\end{array}$ & $\mathrm{H}_{2} \mathrm{O}(\mathrm{l}) \rightarrow \mathrm{H}_{2} \mathrm{O}(\mathrm{v})$ & $+2443\left(25^{\circ} \mathrm{C}\right)$ \\
\hline Calcination & $\mathrm{CaCO}_{3}(\mathrm{~s}) \leftrightarrow \mathrm{CaO}(\mathrm{s})+\mathrm{CO}_{2}(\mathrm{~g})$ & $+1766\left(20^{\circ} \mathrm{C}\right)$ \\
\hline Magnesium carbonate decomposition & $\mathrm{MgCO}_{3}(\mathrm{~s}) \rightarrow \mathrm{MgO}(\mathrm{s})+\mathrm{CO}_{2}(\mathrm{~g})$ & $+1188\left(20^{\circ} \mathrm{C}\right)$ \\
\hline Formation of the liquid phase & $\begin{array}{c}3 \mathrm{CaO}(\mathrm{s})+\mathrm{Al}_{2} \mathrm{O}_{3}(\mathrm{~s}) \rightarrow 3 \mathrm{CaO} \cdot \mathrm{Al}_{2} \mathrm{O}_{3}(\mathrm{~s})\left(\mathrm{C}_{3} \mathrm{~A}\right) \\
4 \mathrm{CaO}(\mathrm{s})+\mathrm{Al}_{2} \mathrm{O}_{3}(\mathrm{~s})+\mathrm{Fe}_{2} \mathrm{O}_{3}(\mathrm{~s}) \rightarrow 4 \mathrm{CaO} \cdot \mathrm{Al}_{2} \mathrm{O}_{3} \cdot \mathrm{Fe}_{2} \mathrm{O}_{3}(\mathrm{~s})\left(\mathrm{C}_{4} \mathrm{AF}\right)\end{array}$ & $\begin{array}{l}-15\left(20^{\circ} \mathrm{C}\right) \\
-84\left(20^{\circ} \mathrm{C}\right)\end{array}$ \\
\hline Formation of silicate dicalcium & $2 \mathrm{CaO}(\mathrm{s})+\mathrm{SiO}_{2}(\mathrm{~s}) \rightarrow$ & $-717\left(20^{\circ} \mathrm{C}\right)$ \\
\hline Formation of tricalcium silicate & $3 \mathrm{CaO}(\mathrm{s})+\mathrm{SiO}_{2}(\mathrm{~s}) \rightarrow \quad 3 \mathrm{CaO} \cdot \mathrm{SiO}_{2}(\mathrm{~s})\left(\mathrm{C}_{3} \mathrm{~S}\right)$ & $-528\left(20^{\circ} \mathrm{C}\right)$ \\
\hline
\end{tabular}

TABLE II

Temperatures of the chemical reactions of clinker production (Paula 2009).

\begin{tabular}{cc}
\hline Temperature & Chemical Reaction \\
\hline Above $800^{\circ} \mathrm{C}$ & Start of the $\mathrm{CaO}$ manufacturing process \\
Between $800^{\circ} \mathrm{C}$ and $1200^{\circ} \mathrm{C}$ & Formation of $\mathrm{C}_{2} \mathrm{~S}$ \\
Between $1095^{\circ} \mathrm{C}$ and $1205^{\circ} \mathrm{C}$ & Formation of $\mathrm{C}_{3} \mathrm{~A}_{\text {and } \mathrm{C}_{4} \mathrm{AF}}$ \\
Between $1260^{\circ} \mathrm{C}$ and $1455^{\circ} \mathrm{C}$ & Formation of $\mathrm{C}_{3} \mathrm{~S}$ from $\mathrm{C}_{2} \mathrm{~S}$ \\
Between $1455^{\circ} \mathrm{C}$ and $1300^{\circ} \mathrm{C}$ & $\mathrm{C}_{2} \mathrm{~S}$ and $\mathrm{C}_{3} \mathrm{~S}$ silicate practically remain unchanged both in form and composition \\
\hline
\end{tabular}


internal operating conditions. Thus, estimating the temperature profile along the kiln is an important object of study.

In a previous work (Spang 1972), a dynamic model was developed. The model was composed of partial differential equations describing the mass balance and the system power (Spang 1972). The model is capable of predicting the concentration and temperature profiles along a rotary kiln operating in counterflow (Spang 1972). A flame model was also developed to quantify the amount of energy supplied to the system (Spang 1972). The equations that comprise this model (Equations 1 to 29) are presented in the Appendix. The results qualitatively describe the behavior of kilns, but the steady state was not reached.

In the present paper, an adaptation of the previous model is implemented to make it more realistic (Spang 1972). Using realistic values of the operational properties provided by a Brazilian company, the concentration and temperature profiles of a real rotary kiln used in the industrial production of the clinker is obtained.

\section{CALCULATION PROCEDURES}

Initially, a modification of the original model (Spang 1972) was performed to obtain a more realistic description of the temperature and concentration profiles of the clinker components along the rotary kiln.
In the originally proposed model (Spang 1972) the variation of gas temperature over time was not considered. To improve the description of the process, an adjustment was made in the gas energy balance (Equation 13 of the Appendix), which consisted of adding a term of gas temperature variation into the equation. In this way, Equation 13 was substituted by Equation 30 .

$$
\begin{aligned}
& A_{g} C_{p g} \rho_{g} v_{g}\left(\frac{\partial T g}{\partial z}\right)=\beta_{1}\left(T_{w}-T_{g}\right)+\beta_{2}\left(T_{s}-T_{g}\right)-C_{p g} \rho_{g} A_{g}\left(\frac{\partial T g}{\partial t}\right)+q_{f} \\
& T_{g}(L, t)=T_{g i}
\end{aligned}
$$

The flame model originally described (Spang 1972) (Equations 17, 18 and 19 of the Appendix) was replaced by an amount of energy supplied to the kiln by the fuel combustion. These changes enable the industrial professional to use the model more directly. In this paper, the quantity of energy proposed for the fuel combustion is constant and equal to $326.7 \mathrm{~kW} / \mathrm{m}(3.9 \times 105 \mathrm{BTU} / \mathrm{ft} . \mathrm{h})$. This amount, adjusted by trial and error, approaches the values commonly used in industry. Thus, the new proposed model is composed of Equations 1-12, 14-16 and 20-30 as listed in the Appendix.

After adaptations, realistic values of the operational properties of the clinker production as reported by a Brazilian industrial plant were employed in the model. The composition of the raw material used in the industrial production of the clinker is shown in Table III. The values were normalized in relation to $\mathrm{CaO}(\mathrm{kg} / \mathrm{kg})$. Other

TABLE III

Input composition of the raw material in the rotary kiln reported by industry.

\begin{tabular}{cc}
\hline Chemical Species & Normalized Composition in relation to $\mathrm{CaO}(\mathrm{kg} / \mathrm{kg})$ \\
\hline $\mathrm{CaCO}_{3}$ & 1.6666 \\
$\mathrm{SiO}_{2}$ & 0.4849 \\
$\mathrm{Al}_{2} \mathrm{O}_{3}$ & 0.1133 \\
$\mathrm{Fe}_{2} \mathrm{O}_{3}$ & 0.0651 \\
$\mathrm{H}_{2} \mathrm{O}$ & 0.0117 \\
\hline
\end{tabular}


TABLE IV

Rotary kiln data reported by industry.

\begin{tabular}{ccc}
\hline Variables & American Units & International System \\
\hline Inlet gas temperature & $1391.67^{\circ} \mathrm{R}$ & $773.15 \mathrm{~K}$ \\
Radio of the kiln (r) & $7.00 \mathrm{ft}$ & $2.15 \mathrm{~m}$ \\
Length of the kiln & $295.28 \mathrm{ft}$ & $90.00 \mathrm{~m}$ \\
Outside radius (r2) & $2.148 \mathrm{~m}$ & $7.05 \mathrm{ft}$ \\
\hline
\end{tabular}

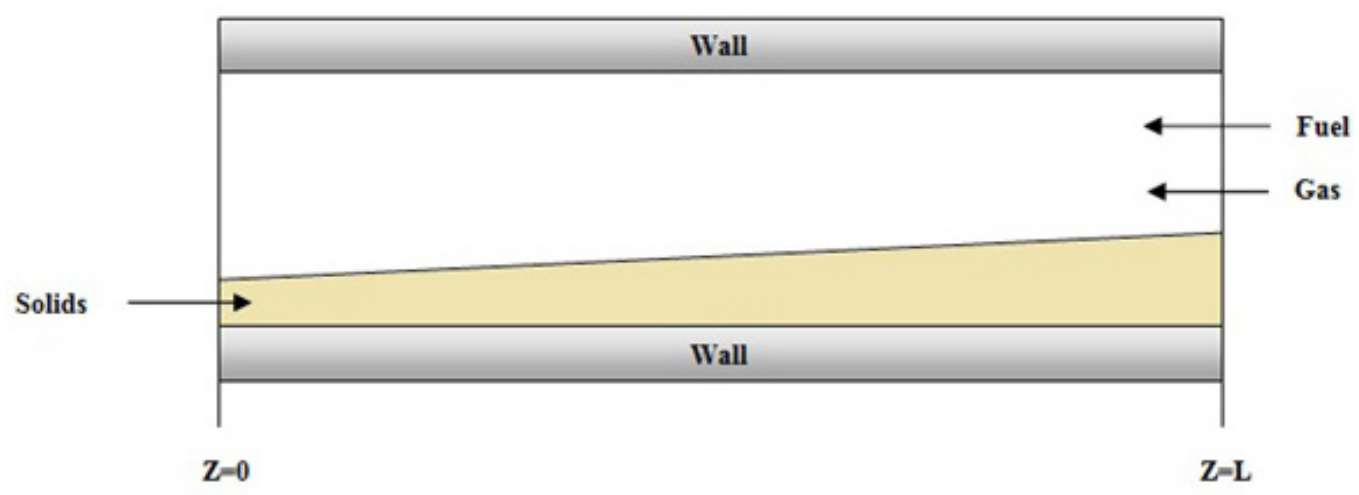

Figure 1 - Volume control used in the mathematical modelling of the rotary kiln (adapted from Spang 1972).

industrial operating properties employed in the model are shown in Table IV. The inner radius of the kiln was estimated to be $1.84 \mathrm{~m}(6.05 \mathrm{ft})$, the initial solid temperature, $562{ }^{\circ} \mathrm{R}(312 \mathrm{~K})$, and the initial temperature of the kiln wall, $662^{\circ} \mathrm{R}(367 \mathrm{~K})$. These estimates were performed based on previous data (Spang 1972) and industrial realities.

The model was solved for different inlet speeds of gas and solid until the final composition of the clinker obtained in the simulation was similar to the actual values obtained in the cement industry ( $\mathrm{V})$. The best values for the gas and the solid inlet speeds were $274.32 \mathrm{~m} / \mathrm{s}(-900 \mathrm{ft} / \mathrm{hr})$ and $5.4864 \mathrm{~m} / \mathrm{s}$ $(18 \mathrm{ft} / \mathrm{hr})$, respectively. Next, the temperature and concentration profiles obtained for the rotary kiln were analyzed considering these values.

For further analysis, the established inlet speed of gas and solid were varied as $-20 \%,-10 \%,+10 \%$ and $+20 \%$ to characterize the differences between the systems profiles. Subsequently, the obtained profiles were analyzed.
The model was solved using the discretization method for finite differences. Forty points of discretization were defined along the length of the rotary kiln. Discretization of the points was implemented according to the incoming stream of gas and solids into the kiln (Figure 1). For the discretization of the equations related to the solids, backward differentiation was used because they are fed into the beginning of the kiln $(\mathrm{z}=0)$, and forward differentiation was used in the equations related to the gas because it is fed into the end of the kiln $(\mathrm{z}=\mathrm{L})$. The ordinary differential equations, functions of time, resulted from the discretization that were resolved by the numerical integrating method of Runge-Kutta with a variable step for error control, with an established tolerance of $10^{-7}$. The model was implemented in Mathcad.

\section{RESULTS AND DISCUSSION}

Successive integrations were made in the model equations until the variations between the results 
were no longer observed, which indicates achievement of the steady state of the rotary kiln. The temperature profiles of the gas, solid, and wall along the kiln's length in continuous operation are presented in Figure 2a. As expected, the kiln's temperature increases along its length to a maximum and then decays.

The $\mathrm{CaCO}_{3}$ concentration profile along the length of the kiln is shown in Figure $2 b$. The profile follows the general pattern of a previous simulation (Spang 1972). Initially, there is a high concentration of $\mathrm{CaCO}_{3}$ that decreases along the length of the kiln until it reaches zero.

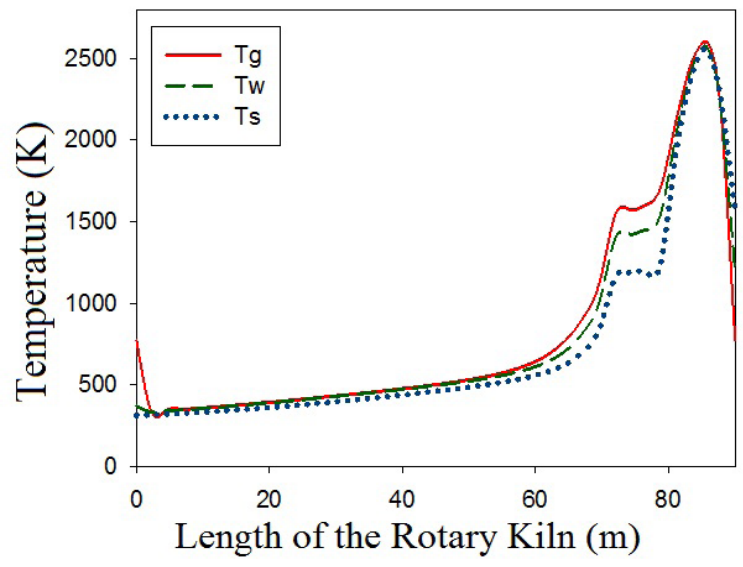

(a)

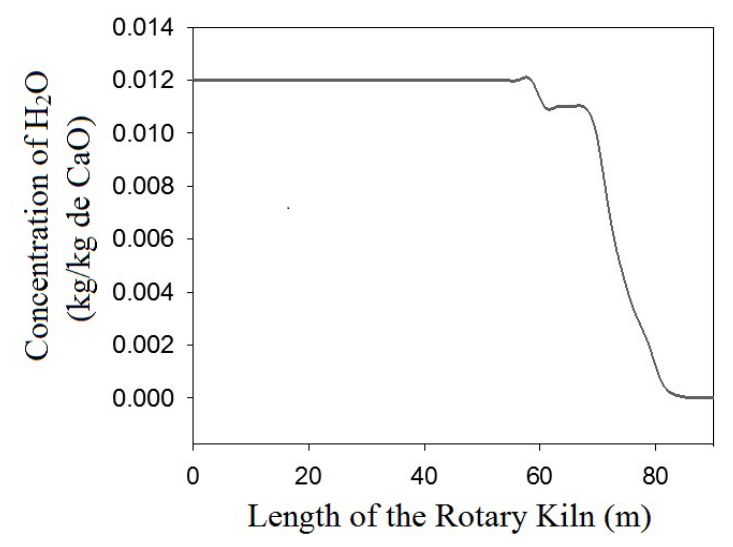

(c)
The water concentration profile along the length of the kiln in steady state is shown in Figure $2 c$. The concentration of molecular water contained in the beginning of the feeding of solids decreases along the kiln until it becomes zero, as expected.

The concentration profiles of $\mathrm{C}_{3} \mathrm{~S}, \mathrm{C}_{2} \mathrm{~S}$, $\mathrm{C}_{3} \mathrm{~A}, \mathrm{C}_{4} \mathrm{AF}$, and $\mathrm{CaO}$ along the length of the kiln in continuous operation are shown in Figure 2d. A decreasing behavior in the concentration of reactants followed by the formation of the clinker components is observed, which is in agreement with the expected.

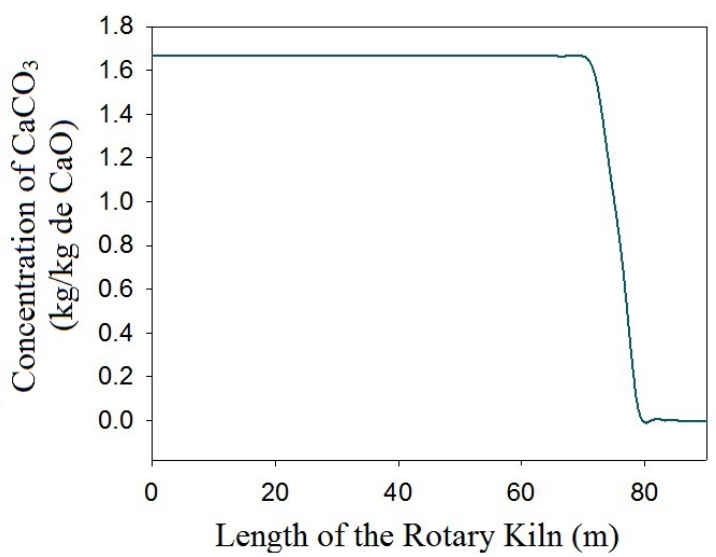

(b)

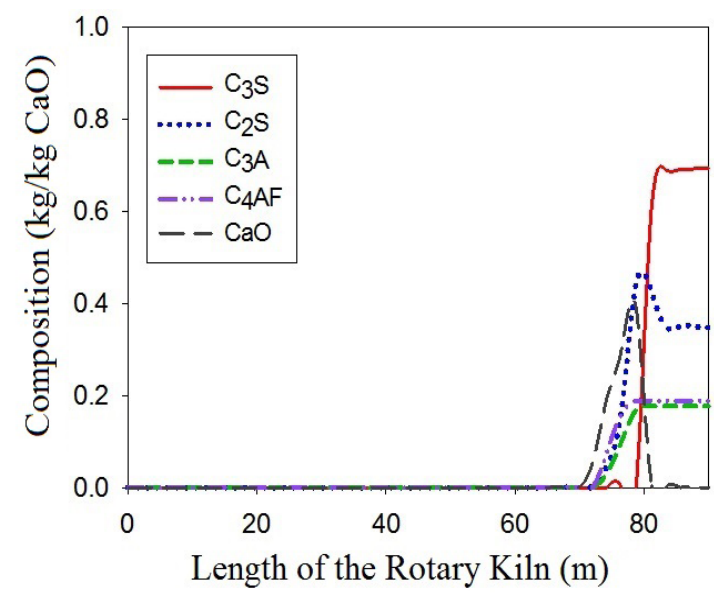

(d)

Figure 2 - Temperature profiles of the gas, the solid and the industrial rotary kiln's wall (a); concentration profiles of CaCO3 (b); concentration profiles of water (c) and concentration profiles of $\mathrm{C} 3 \mathrm{~S}, \mathrm{C} 2 \mathrm{~S}, \mathrm{C} 3 \mathrm{AF}$ and $\mathrm{CaO}(\mathbf{d})$ in the industrial rotary kiln at steady state. 
The clinker composition simulated by the model and the industrial clinker composition are presented in Table V. The final concentrations of the clinker components obtained by the model are relatively close to the actual concentrations of the cement industry. The $\mathrm{CaO} \cdot \mathrm{Al}_{2} \mathrm{O}_{3}$ and $12 \mathrm{CaO} \cdot 7 \mathrm{Al}_{2} \mathrm{O}_{3}$ elements were not taken into consideration during modelling because they were not considered as part of the main elements of the clinker formation. The authors believe that this consideration caused the difference between the real (industrial composition) and the simulated composition of $3 \mathrm{CaO} \cdot \mathrm{Al}_{2} \mathrm{O}_{3}$ presented in TableV.

Note that the final composition of the clinker widely varies from one industry to another and may vary even between operations of a same kiln because the composition of raw material is not constant, i.e., it may depend on the natural sources. In addition, changes in the operating conditions of a kiln produces variances in the final clinker concentration. An important aspect to highlight is that during the simulation of the actual system, it was not trivial to set values of inlet gas flow and solid flow that together satisfied the required values for the profiles of temperature and clinker concentration.

The profiles of temperature and clinker concentration obtained by varying the inlet gas speed by $-20 \%,-10 \%,+10 \%$ and $+20 \%$ are shown in Figures 3 and 4, respectively. The temperature profiles in Figure 3 are very similar, with only slight differences in the shapes of the temperature peaks noticed. In Figure 4, it is observed that $\mathrm{C}_{3} \mathrm{~A}, \mathrm{C}_{4} \mathrm{AF}$ and $\mathrm{CaO}$ have similar profiles in all of the proposed systems, whereas $\mathrm{C}_{3} \mathrm{~S}$ and $\mathrm{C}_{2} \mathrm{~S}$ have different profiles in each one of them. In general, the increase of the inlet gas speed from $-20 \%$ to $+10 \%$ increases the final concentration of $\mathrm{C}_{3} \mathrm{~S}$ and decreases the final concentration of $\mathrm{C}_{2} \mathrm{~S}$. However, with $+20 \%$ increase of inlet gas speed there is a decrease of the final concentration of $\mathrm{C}_{3} \mathrm{~S}$ and an increase of $\mathrm{C}_{2} \mathrm{~S}$ concentration.

As the quantity of energy proposed for the fuel combustion is constant, the increase of the inlet gas speed increases the energy transfer from the solid that is near the output of the kiln to the solid inside the equipment. The energy transfer is responsible for the increase of temperature inside the kiln, which is necessary for the chemical reactions to occur (Table II). The increase of the inlet gas speed from $-20 \%$ to $+10 \%$ increases the consumption of $\mathrm{C}_{2} \mathrm{~S}$ and the production of $\mathrm{C}_{3} \mathrm{~S}$ while $\mathrm{CaO}$ is available (Figure $4 a, b$ and c). A $+20 \%$ increase of the inlet gas speed strongly promotes the formation of $\mathrm{C}_{2} \mathrm{~S}$, produced in lower temperatures than $\mathrm{C}_{3} \mathrm{~S}$ (Table II), and consequently reduces the availability of $\mathrm{CaO}$ in the system. Therefore, even with an increase of temperature, the production of $\mathrm{C}_{3} \mathrm{~S}$ is limited (Figure $4 \mathrm{~d}$ ).

The temperature and clinker concentration profiles that were obtained by varying the inlet solid speed by $-20 \%,-10 \%,+10 \%$ and $+20 \%$ are shown

TABLE V

Comparison of the results obtained by the model and the industrial composition of the clinker.

\begin{tabular}{ccc}
\hline Chemical Species & Industrial Composition of the Clinker (mol/mol) & Simulated Composition of the Clinker (mol/mol) \\
\hline $3 \mathrm{CaO} \cdot \mathrm{SiO}_{2}$ & 0.5600 & 0.4630 \\
$2 \mathrm{CaO} \cdot \mathrm{SiO}_{2}$ & 0.2215 & 0.3074 \\
$\mathrm{CaO} \cdot \mathrm{Al}_{2} \mathrm{O}_{3}$ & 0.0848 & - \\
$12 \mathrm{CaO} .7 \mathrm{Al}_{2} \mathrm{O}_{3}$ & 0.0087 & - \\
$3 \mathrm{CaO} . \mathrm{Al}_{2} \mathrm{O}_{3}$ & 0.0816 & 0.1706 \\
$4 \mathrm{CaO} . \mathrm{Al}_{2} \mathrm{O}_{3} \cdot \mathrm{Fe}_{2} \mathrm{O}_{3}$ & 0.0433 & 0.0589 \\
$\mathrm{CaO}$ & 0.0000 & 0.0000 \\
$\mathrm{TOTAL}$ & 0.9999 & 0.9999 \\
\hline
\end{tabular}




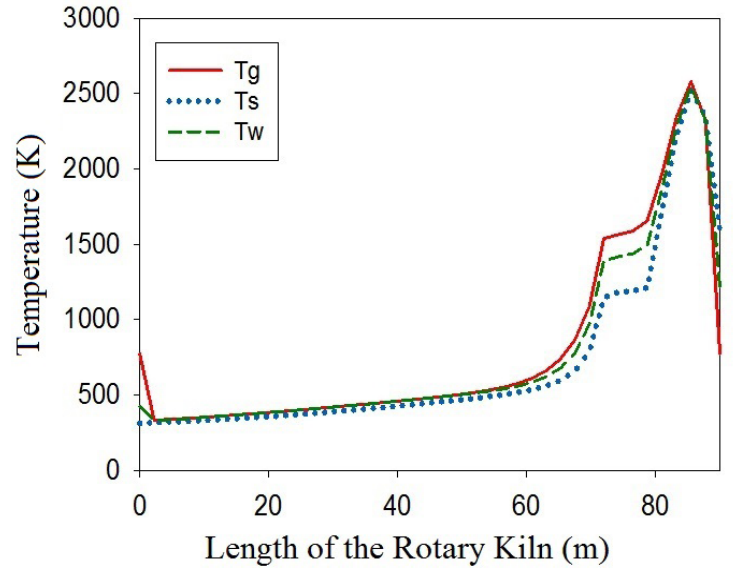

(a)

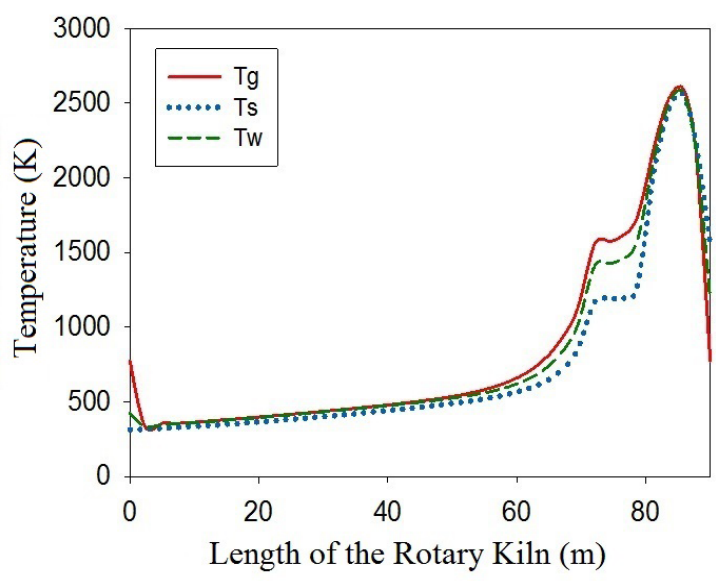

(c)

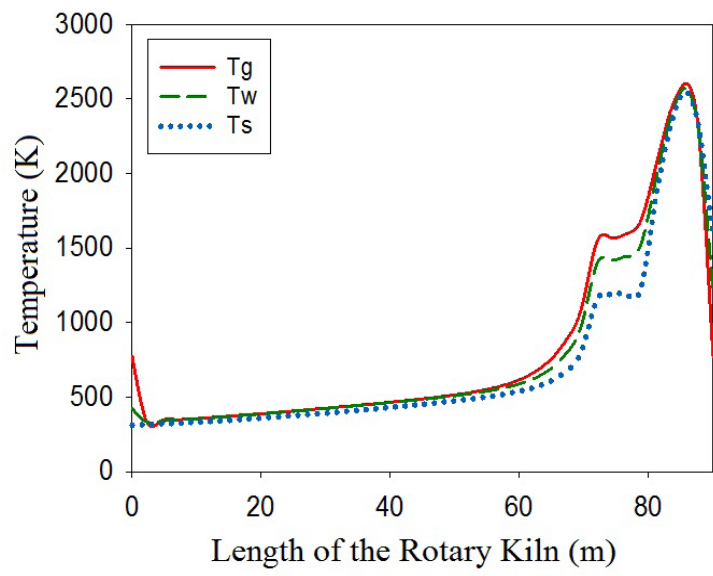

(b)

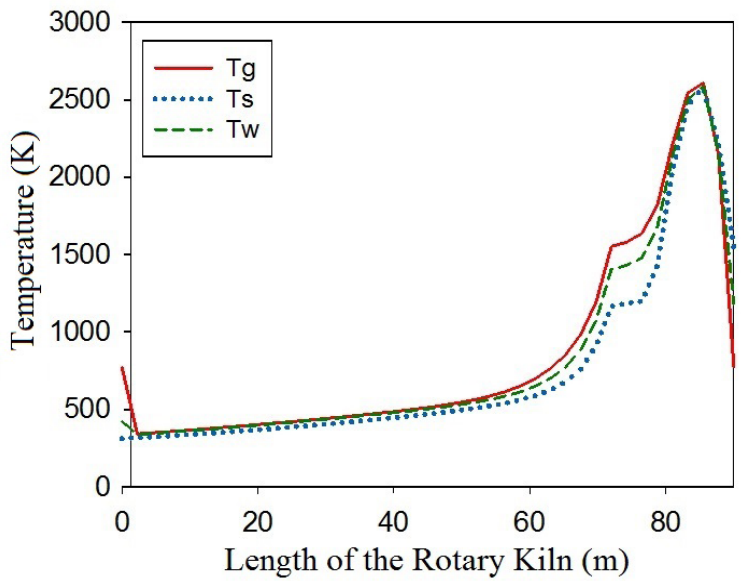

(d)

Figure 3 - Temperature profiles of the gas (Tg), the solid (Ts), and the wall (Tw) of the industrial rotary kiln at the steady state. (a) $-20 \%$ of inlet gas speed; (b) $-10 \%$ of inlet gas speed; (c) $+10 \%$ of inlet gas speed; (d) $+20 \%$ of inlet gas speed.

in Figures 5 and 6, respectively. In Figure 5, it is observed that the temperature of the burning zones, which correspond to the highest peak, decrease with the increase of the inlet solid speed. There is also an enlargement of the transition zone that corresponds to the second highest peak. In Figure 6, the concentrations of $\mathrm{C}_{3} \mathrm{~A}, \mathrm{C}_{4} \mathrm{AF}$ and $\mathrm{CaO}$ along the kiln have relatively similar profiles in all of the proposed systems, whereas $\mathrm{C}_{3} \mathrm{~S}$ and $\mathrm{C}_{2} \mathrm{~S}$ have different profiles in each one of them. The increase of the inlet solid speed promotes a later formation of $\mathrm{C}_{3} \mathrm{~S}$ through the length of the kiln and decrease in the $\mathrm{C}_{3} \mathrm{~S}$ final concentration. There is also an increase in the final concentration of $\mathrm{C}_{2} \mathrm{~S}$.

As the formation of $\mathrm{C}_{3} \mathrm{~A}$ and $\mathrm{C}_{4} \mathrm{AF}$ occurs before $1205^{\circ} \mathrm{C}$ (Table II), a reduction of temperature in the system (Figure 5) does not significantly affect the production of these species, which is not true for $\mathrm{C}_{3} \mathrm{~S}$ that are formed at higher temperatures (Table II). An increase of the inlet solid speed promotes a decrease of the temperature profile of the kiln and consequently reduces the formation of $\mathrm{C}_{3} \mathrm{~S}$ from $\mathrm{C}_{2} \mathrm{~S}$, which occurs at temperature above $1260{ }^{\circ} \mathrm{C}$ (Figure 2). For this reason the profiles of $\mathrm{C}_{3} \mathrm{~S}$ and $\mathrm{C}_{2} \mathrm{~S}$ are modified. 


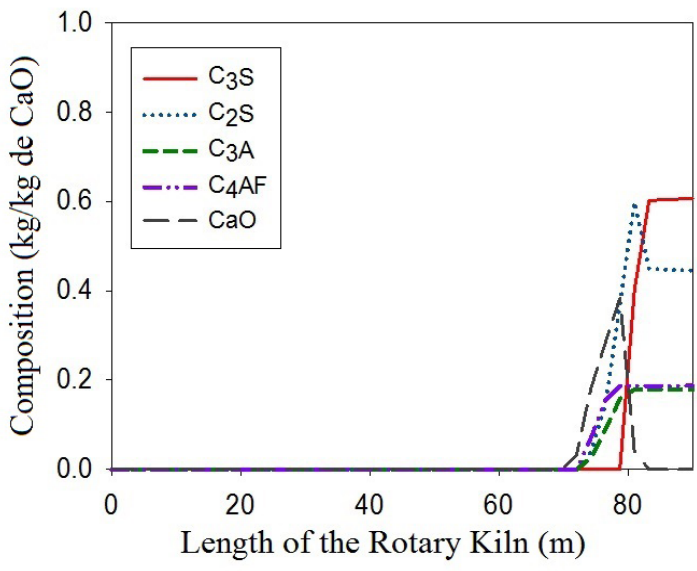

(a)

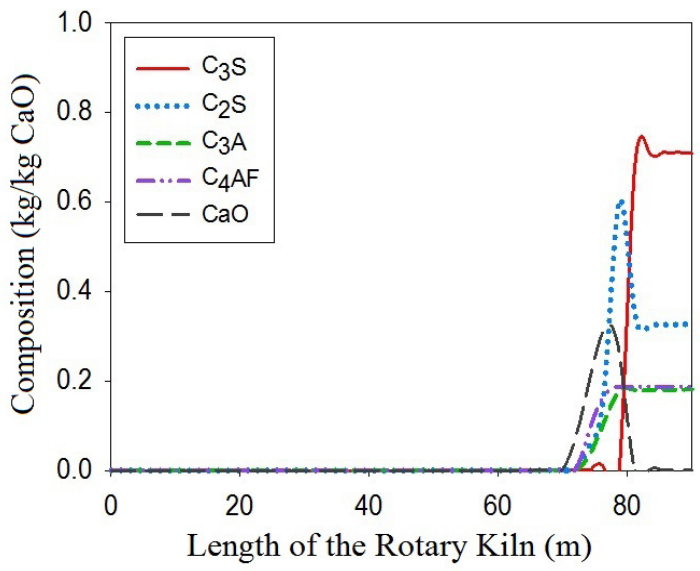

(c)

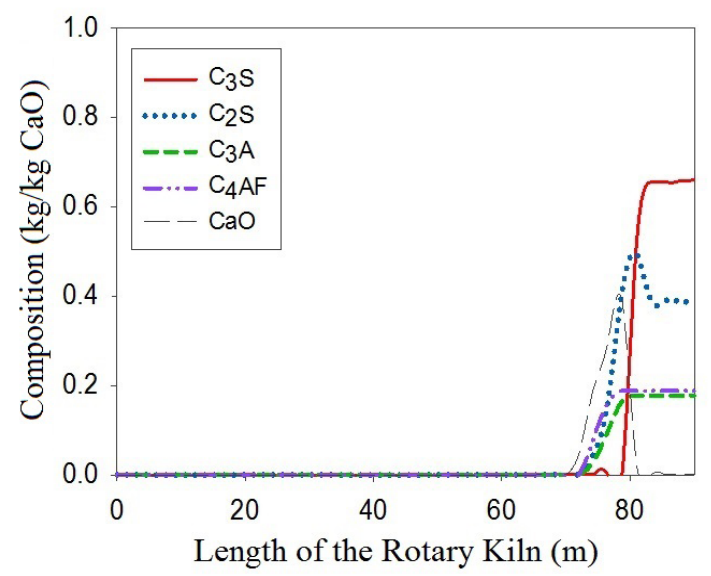

(b)

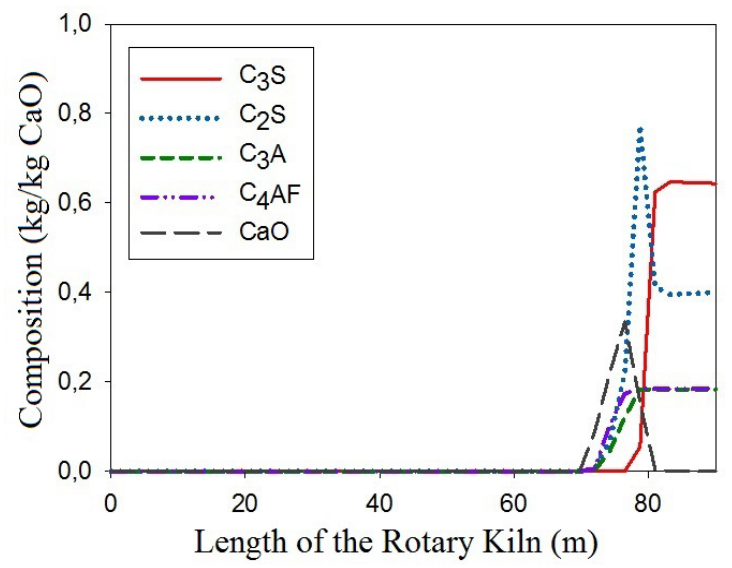

(d)

Figure 4 - Concentration profiles of $\mathrm{C}_{3} \mathrm{~S}, \mathrm{C}_{2} \mathrm{~S}, \mathrm{C}_{3} \mathrm{~A}, \mathrm{C}_{4} \mathrm{AF}$ and $\mathrm{CaO}$ in the industrial rotary kiln at steady state. (a) -20\% of inlet solid speed; (b) $-10 \%$ of inlet solid speed; (c) $+10 \%$ of inlet solid speed; (d) $+20 \%$ of inlet solid speed. 


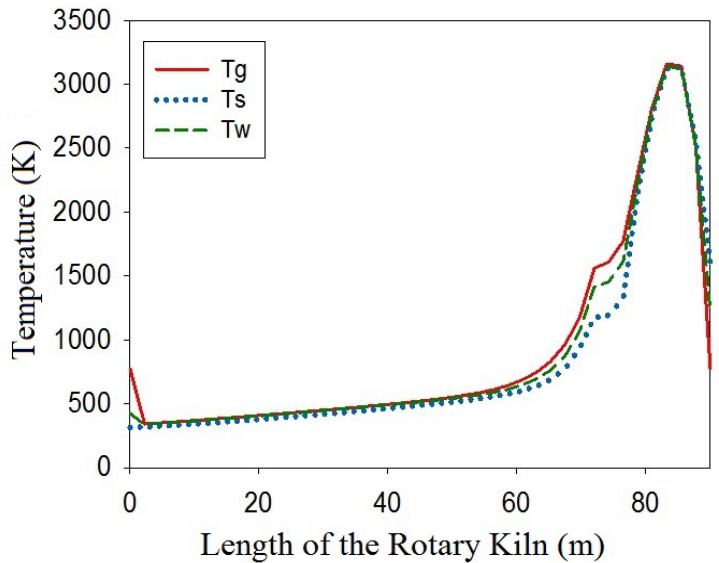

(a)

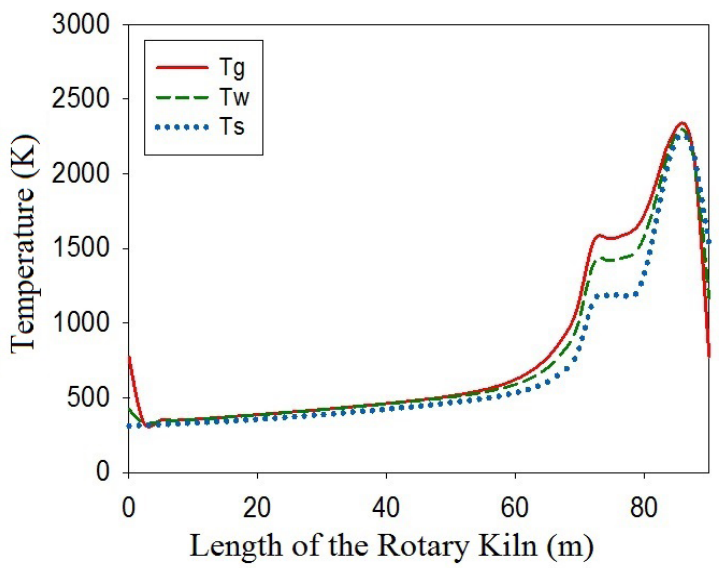

(c)

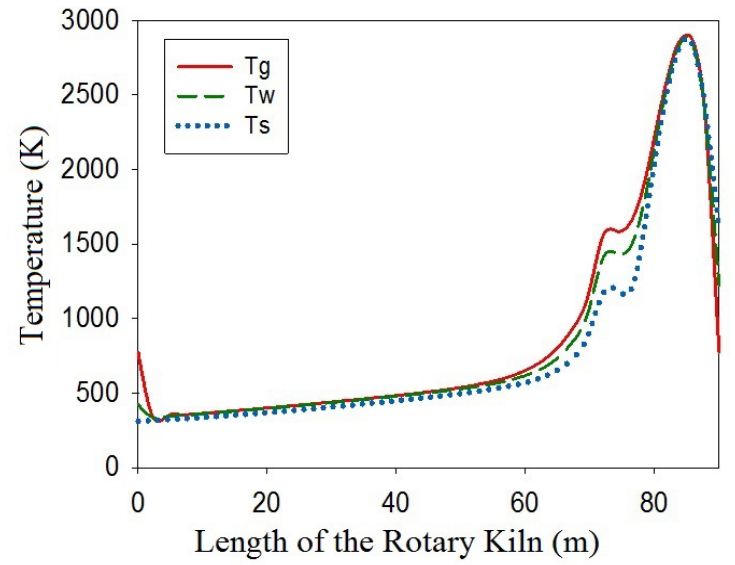

(b)

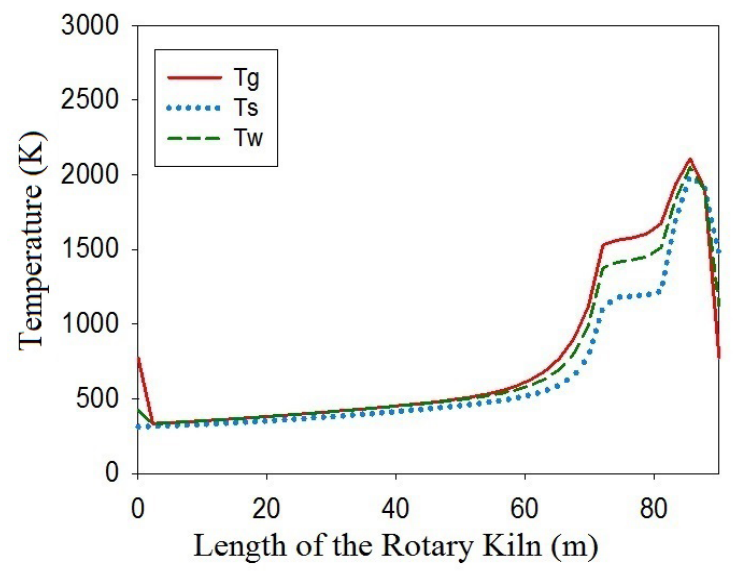

(d)

Figure 5 - Temperature profiles of the gas, the solid, and the wall of the industrial rotary kiln at steady state. (a) $-20 \%$ of inlet solid speed; (b)- $10 \%$ of inlet solid speed; (c) $+10 \%$ of inlet solid speed; (d) $+20 \%$ of inlet solid speed 


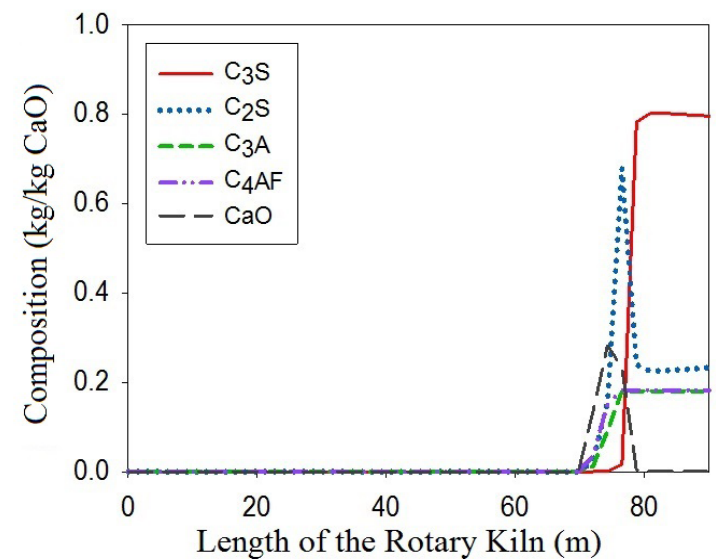

(a)

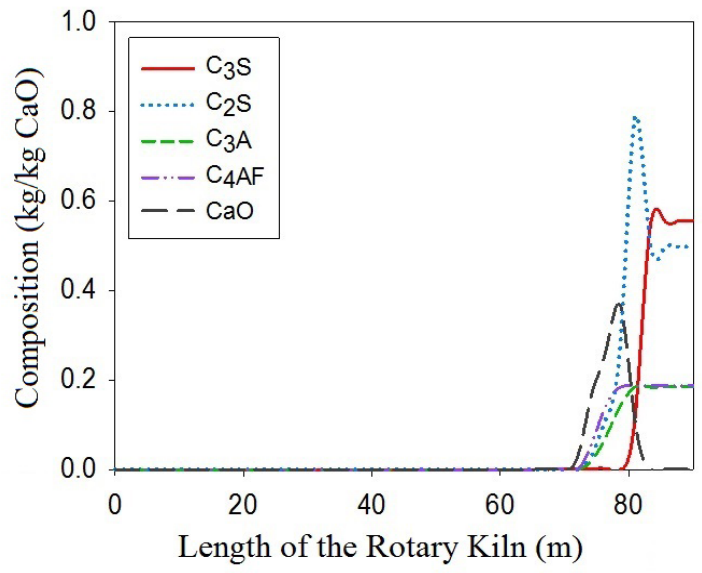

(c)

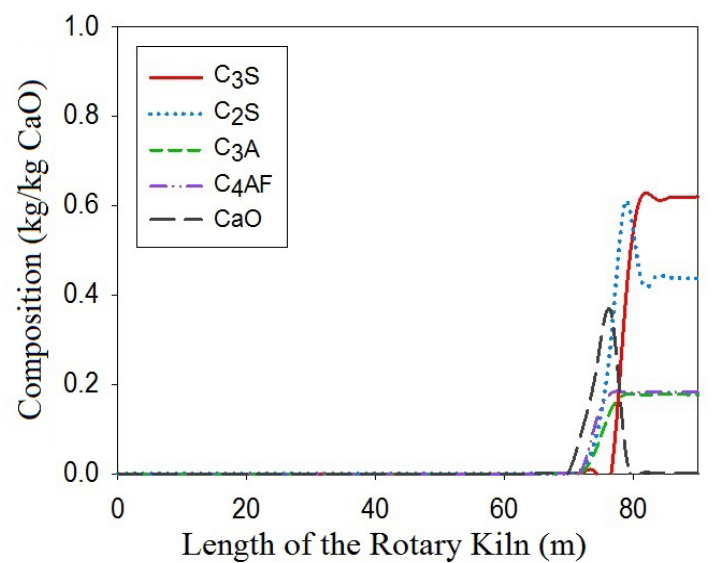

(b)

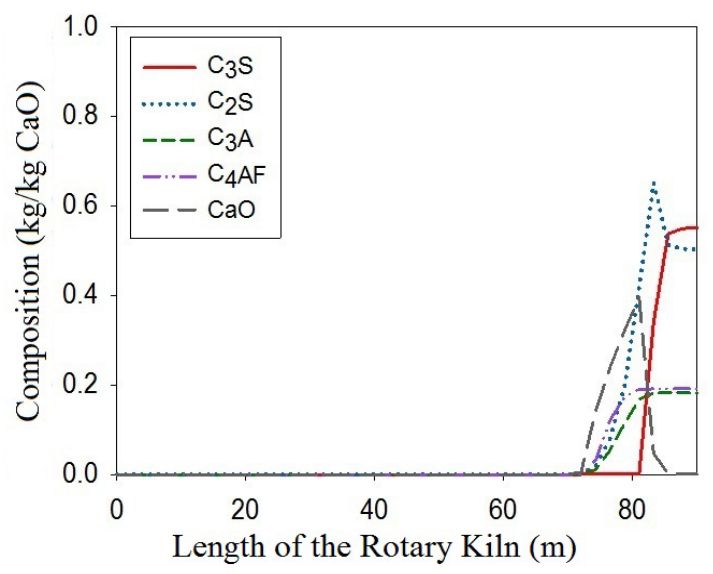

(d)

Figure 6 - Concentration profiles of $\mathrm{C}_{3} \mathrm{~S}, \mathrm{C}_{2} \mathrm{~S}, \mathrm{C}_{3} \mathrm{~A}, \mathrm{C}_{4} \mathrm{AF}$ and $\mathrm{CaO}$ in the industrial rotary kiln at steady state. (a) $-20 \%$ of inlet gas speed; (b) $-10 \%$ of inlet gas speed; (c) $+10 \%$ of inlet gas speed; (d) $+20 \%$ of inlet gas speed. 


\section{CONCLUSIONS}

A mathematical model able to describe the temperature and concentration profiles of the clinker components along a real rotary kiln, in continuous operation, was developed. The mathematical model proposed in this paper does not require advanced computing to be solved, and it is easily adaptable to new industrial realities.

Variations of the gas and solid inlet speeds by
$-20 \%,-10 \%,+10 \%$ and $+20 \%$ were individuality analysed according to the resulting temperature and concentration profiles of the clinker. These results were obtained via the model in the simulation of the real process. These parameters of operation were chosen because they have a significant influence in the process of cement production, and they can be changed without much modification in the kiln. In addition, these parameters can be used to find new operating conditions for the equipment.

\section{NOMENCLATURE}

\begin{tabular}{|c|c|c|c|}
\hline & Notation & Value & Unit \\
\hline $\mathrm{f} 2$ & Coefficient of conduction - solid to gas & 4 & $\left(\mathrm{Btu} /\left(\mathrm{h}(\mathrm{ft})^{2 \circ} \mathrm{F}\right)\right.$ \\
\hline f3 & Coefficient of conduction - wall to solid & 4 & $\left(\mathrm{Btu} /\left(\mathrm{h}(\mathrm{ft})^{2 \circ} \mathrm{F}\right)\right.$ \\
\hline $\mathrm{f} 4$ & Coefficient of conduction - wall to outside air & 0.7 & $\left(\mathrm{Btu} /\left(\mathrm{h}(\mathrm{ft})^{2 \circ} \mathrm{F}\right)\right.$ \\
\hline $\mathrm{F}$ & $\# \mathrm{Fe}_{2} \mathrm{O}_{3} / \# \mathrm{CaO}$ & & \\
\hline $\mathrm{F}_{\mathrm{i}}$ & Initial value of $\# \mathrm{Fe}_{2} \mathrm{O}_{3} / \# \mathrm{CaO}$ & 0.0469 & $\# / \# \mathrm{CaO}$ \\
\hline $\mathrm{G}_{\mathrm{F}}$ & Amount of fuel per hour & 53000 & $\# / \mathrm{h}$ \\
\hline $\mathrm{h}_{0}$ & Fraction of radiation & 0.0758 & \\
\hline $\mathrm{K}$ & Thermal conductivity of the wall & 0.9 & $\left(\mathrm{Btu} /\left(\mathrm{h}(\mathrm{ft})^{2 \circ} \mathrm{F}\right)\right.$ \\
\hline $\mathrm{K}_{\mathrm{f}}$ & Radiation rate - fuel & & $1 / \mathrm{h}$ \\
\hline $\mathrm{k}_{1}$ & Radiation rate $-\mathrm{CaCO}_{3}$ & & $1 / \mathrm{h}$ \\
\hline $\mathrm{k}_{\alpha}$ & Radiation rate $-\mathrm{C}_{3} \mathrm{~S}$ & & $1 / \mathrm{h}$ \\
\hline $\mathrm{k}_{\beta}$ & Radiation rate $-\mathrm{C}_{2} \mathrm{~S}$ & & $1 / \mathrm{h}$ \\
\hline $\mathrm{K} \gamma$ & Radiation rate $-\mathrm{C}_{3} \mathrm{~A}$ & & $1 / \mathrm{h}$ \\
\hline $\mathrm{K} \delta$ & Radiation rate $-\mathrm{C}_{4} \mathrm{AF}$ & & $1 / \mathrm{h}$ \\
\hline $\mathrm{K} \omega$ & Radiation rate - water & & $1 / \mathrm{h}$ \\
\hline $\mathrm{L}$ & Total length of the kiln & 400 & $\mathrm{ft}$ \\
\hline M & $\begin{array}{c}\text { Depending on the subscript molecular weight of the } \\
\text { chemicals }\end{array}$ & & \\
\hline${ }^{\mathrm{M}} \mathrm{C}_{1}$ & Molecular weight of Carbon (C) & & $\mathrm{lb}$ \\
\hline $\mathrm{P}$ & Pressure & & $\mathrm{Btu} / \mathrm{ft}^{2}$ \\
\hline $\mathrm{P}$ & Angle subtended by the surface of solid & $3 \pi / 2$ & Radians \\
\hline Qc & Heat generated by the chemical reactions & & $(\mathrm{Btu} /(\mathrm{ft} 3 \mathrm{~h}))$ \\
\hline $\mathrm{qF}$ & Heat generated by the fuel & & $(\mathrm{Btu} /(\mathrm{ft} \mathrm{h}))$ \\
\hline $\mathrm{R}$ & Ideal Gas constant & 1.987 & Btulbmol ${ }^{-1} \mathrm{R}^{-1}$ \\
\hline Q & Heat generated or moving into a region & & \\
\hline $\mathrm{r}_{\mathrm{F}}$ & Particle size of the fuel & $10^{-2}$ & $\mathrm{ft}$ \\
\hline $\mathrm{r}_{1}$ & Inside radius of the kiln & 5 & $\mathrm{ft}$ \\
\hline $\mathrm{r}_{2}$ & Outside radius of the kiln & 6 & $\mathrm{ft}$ \\
\hline $\mathrm{r}_{3}$ & Ratio of heat transfer in the chain section & 5 & $\mathrm{ft}$ \\
\hline
\end{tabular}




\begin{tabular}{|c|c|c|c|}
\hline & Notation & Value & Unit \\
\hline $\mathrm{R} \omega$ & Reaction rate of water & & {$\left[\mathrm{h}^{-1}\right]$} \\
\hline S & $\# \mathrm{SiO}_{2} / \# \mathrm{CAO}$ & & \\
\hline $\mathrm{S}_{\mathrm{i}}$ & Initial value of $\# \mathrm{SiO}_{2} / \# \mathrm{CAO}$ & 0.3398 & \#/\#CAO \\
\hline $\mathrm{T}_{\mathrm{a}}$ & Temperature outside the kiln & 561.7 & ${ }^{\circ} \mathrm{R}$ \\
\hline $\mathrm{T}_{\mathrm{g}}$ & Temperature of the solid & & ${ }^{\circ} \mathrm{R}$ \\
\hline $\mathrm{T}_{\mathrm{gi}}$ & Input temperature of the gas & 1700 & ${ }^{\circ} \mathrm{R}$ \\
\hline $\mathrm{T}_{\mathrm{s}}$ & Temperature of the solid & & ${ }^{\circ} \mathrm{R}$ \\
\hline $\mathrm{T}_{\mathrm{si}}$ & Initial temperature of the solid & 562 & ${ }^{\circ} \mathrm{R}$ \\
\hline $\mathrm{T}_{\mathrm{w}}$ & Temperature of the wall & & ${ }^{\circ} \mathrm{R}$ \\
\hline $\mathrm{v}_{\mathrm{g}}$ & Velocity of the gas & 40000 & $\mathrm{ft} / \mathrm{h}$ \\
\hline $\mathrm{v}_{\mathrm{s}}$ & Velocity of the solid & -150 & $\mathrm{ft} / \mathrm{h}$ \\
\hline Z & Distance along the kiln & & $\mathrm{ft}$ \\
\hline A & $\# \mathrm{C}_{3} \mathrm{~S} / \# \mathrm{CAO}$ & & \\
\hline B & $\# \mathrm{C}_{2} \mathrm{~S} / \# \mathrm{CAO}$ & & \\
\hline$\beta_{1}, \beta_{2}, \beta_{3}, \beta_{4}$ & Heat transfer coefficient & & $\left(\mathrm{Btu} /\left(\mathrm{h}^{\circ} \mathrm{R}\right)\right)$ \\
\hline$\gamma$ & $\# \mathrm{C}_{3} \mathrm{~A} / \# \mathrm{CaO}$ & & \\
\hline$\delta$ & $\# \mathrm{C}_{4} \mathrm{AF} / \# \mathrm{CaO}$ & & \\
\hline$\Delta \mathrm{H}_{\xi}$ & Heat of reaction $-\mathrm{CaCO}_{3}$ & 1275 & $\mathrm{Btu} / \# \mathrm{CaCO}_{3}$ \\
\hline$\Delta \mathrm{H}_{\mathrm{F}}$ & Heat of reaction - fuel & -14000 & $\mathrm{Btu} / \# \mathrm{CaCO}_{3}$ \\
\hline$\Delta \mathrm{H}_{\alpha}$ & Heat of reaction $-\mathrm{C}_{3} \mathrm{~S}$ & 11 & $\mathrm{Btu} / \#_{\mathrm{C}_{3} \mathrm{~S}}$ \\
\hline$\Delta \mathrm{H}_{\beta}$ & Heat of reaction $-\mathrm{C}_{2} \mathrm{~S}$ & -381 & $\mathrm{Btu} / \# \mathrm{C}_{2} \mathrm{~S}$ \\
\hline$\Delta \mathrm{H}_{\omega}$ & Heat of reaction - water & 970 & Btu/\#water \\
\hline$\varepsilon_{\mathrm{g}}$ & Radiation coefficient - gas & 0.273 & \\
\hline$\varepsilon_{\mathrm{s}}$ & Radiation coefficient - solid & 0.500 & \\
\hline$\varepsilon_{\mathrm{w}}$ & Radiation coefficient - wall & 0.751 & \\
\hline$\xi$ & $\# \mathrm{CaCO}_{3} / \# \mathrm{CaO}$ & & \\
\hline$\xi_{\mathrm{i}}$ & Initial value of $\# \mathrm{CaCO}_{3} / \# \mathrm{CaO}$ at the input & 1.784 & $\# / \# \mathrm{CaO}$ \\
\hline$\rho_{\mathrm{F}}$ & Density of the fuel & & $\# / \# \mathrm{ft}^{3}$ \\
\hline$\rho_{\mathrm{g}}$ & Density of the gas & 0.05 & $\# / \# \mathrm{ft}^{3}$ \\
\hline$\rho_{\mathrm{s}}$ & Density of the solid & 56 & $\# / \# \mathrm{ft}^{3}$ \\
\hline$\rho_{\mathrm{w}}$ & Density of the wall & 112 & $\# / \# \mathrm{ft}^{3}$ \\
\hline$\Psi$ & $\# \mathrm{CO}_{2} / \# \mathrm{CaO}$ & & \\
\hline$\omega$ & $\#$ water/\#CaO & & \\
\hline$\omega_{i}$ & Initial value of \#water/\# $\mathrm{CaO}$ & 0.0649 & $\# / \# \mathrm{CaO}$ \\
\hline
\end{tabular}

\section{REFERENCES}

ATMACA A AND YUMRUTA R. 2014. Analysis of the parameters affecting energy consumption of a rotary kiln in cement industry. Appl Therm Eng 66: 435-444.

ATSONIOS KP, GRAMMELIS SK, ANTIOHOS N, NIKOLOPOULOS E AND KAKARAS EM. 2015. Integration of calcium looping technology in existing cement plant for $\mathrm{CO} 2$ capture: Process modelling and technical considerations. Fuel 153: 210-223.

BOATENG AA AND BARR PV. 1996. A thermal model for the rotary kiln including heat transfer within the bed. Pergamon 39: 2131-2147.

COPERTARO E, CHIARIOTTI D, ESTUPINAN A, ALVARO N, PAONE B, PETERS GM AND REVEL A. 2015. discrete-continuous approach to describe $\mathrm{CaCO}_{3}$ 
decarbonation in non-steady thermal conditions. Powder Technol 275: 131-138.

DEL COZ DÍAZ JJ, MAZÓNA F, RODRIGUES N, GARCÍA D AND SUÁREZ FJ. 2002. Design and finite element analysis of a wet cycle cement rotary kiln. Finite Elem Anal Des 39: 17-42.

GARTNER EM AND MACPHEE DE. 2011. A physicochemical basis for novel cementitious binders. Cement Concrete Res 41: 736-749.

KADDATZ KT, RASUL MG AND AZAD R. 2013. Alternative fuels for use in cement kilns: process impact modelling. Procedia Engineering 56: 413-420.

KIHARA Y AND VISEDO G. 2014. A indústria do cimento e o desenvolvimento do Brasil. Associação Brasileira de Cimento Portland. Disponível em: <http://www.abcp. org.br/conteudo/imprensa/a-industria-do-cimento-e-odesenvolvimento-do-brasil\#.VQLvgo7F9NP>. Acesso em: 19/05/2015.

LOURENÇO RR, ANGÉLICA RS AND RODRIGUES JA. 2013. Preparation of refractory calcium aluminate cement using the sonochemical process. Mat Res 16: 731-739.

MUJUMDARA KSB, GANESHA KV, KULKARNIA SB AND RANADE VV. 2007. Rotary Cement Kiln Simulator (RoCKS): Integrated modeling of pre-heater, calciner, kiln and clinker cooler. Chem Eng Sci 69: 2590-2607.

PAULA LG. 2009. Análise termoeconômica do processo de produção de cimento Portland com co-processamento de misturas de resíduos, Brasil: Universidade Federal de Itajubá.

SAIDUR R, HOSSAINA MS, ISLAMA MR, FAYAZ H AND MOHAMMED HA. 2011. A review on kiln system modelling. Renew Sust Energ Rev 15: 2487-2500.

SCHNEIDER M, ROMER M, TSCHUDIN M AND BOLIO H. 2011. Sustainable cement production - present and future. Cement Concrete Res 41: 642-650.

SILVA MCC. 2007. Relações entre micestrutura, composição, resistência à ruptura e moabilidade de clínqueres de cimento Portland, Brazil: COPPE/UFRJ.

SMITH JM, VAN NESS HC AND ABBOTT MM. 2007. Introdução à termodinâmica da Engenharia Química, Rio de Janeiro: Ed. LTC, 644 p.

SPANG HA. 1972. A dynamic model of a cement kiln. Pergamon Press 8: 309-323.

STADLER KS, POLAND J AND GALLESTEY E. 2011. Model predictive control of a rotary cement kiln. Control Eng Pract 19: 1-9.

TSAMATSOULIS DC. 2014. Optimizing the control system of cement milling: process modeling and controller tuning based on loop shaping procedures and process simulations. Braz J Chem Eng 31: 155-170.

UTLU Z, SOGUT Z, HEPBASLI A AND OKTAY Z. 2006. Energy and exergy analyses of a raw mill in a cement production. Appl Therm Eng 26: 2479-2489.

\section{APPENDIX}

Material balance equations:

Water: $\frac{\partial \omega}{\partial t}=-R_{\omega}-v_{s} \frac{\partial \omega}{\partial z}, R_{\omega}=K_{\omega} \omega \omega \leq 0.1=\omega(0, t)=\omega_{i} K_{\omega} \omega>0.1$

$\mathrm{CO} 2: \frac{\partial \Psi}{\partial t}=\frac{A_{s}}{A_{g}} \frac{\rho_{s}}{\rho_{g}} \frac{M_{\Psi}}{M_{C}} k_{1} \xi-v_{g} \frac{\partial \Psi}{\partial z}, \Psi(L, t)=0$

$\mathrm{CaCO} 3: \frac{\partial \xi}{\partial t}=-k_{1} \xi \frac{M \xi}{M_{C}}-v_{s} \frac{\partial \xi}{\partial z}, \xi(0, t)=\xi_{1}$

$\mathrm{C}_{3} \mathrm{~S}: \frac{\partial \alpha}{\partial t}=\frac{M \alpha}{M_{C}} k_{\alpha}(C) \beta-v_{s} \frac{\partial \alpha}{\partial z}, \alpha(0, t)=0$

$\mathrm{C}_{2} \mathrm{~S}: \frac{\partial \beta}{\partial t}=\frac{M \beta}{2 M_{C}} k_{\beta}\left(C^{2}\right) S-\frac{M \beta}{M_{C}} k_{\alpha}(C) \beta-v_{s} \frac{\partial \beta}{\partial z}, \beta(0, t)=0$

$\mathrm{C}_{3} \mathrm{~A}: \frac{\partial \gamma}{\partial t}=\frac{M \gamma}{3 M_{C}} k_{\gamma}\left(C^{3}\right) A-v_{s} \frac{\partial \gamma}{\partial z}, \gamma(0, t)=0$

$\mathrm{C}_{4} \mathrm{AF}: \frac{\partial \delta}{\partial t}=\frac{M \delta}{4 M_{C}} k_{\delta}\left(C^{4}\right) A F-v_{s} \frac{\partial \delta}{\partial z}, \delta(0, t)=0$

$\mathrm{Fe}_{2} \mathrm{O}_{3}: \frac{\partial F}{\partial t}=-\frac{M_{F}}{4 M_{C}} k_{\delta}\left(C^{4}\right) A F-v_{s} \frac{\partial F}{\partial z}, F(0, t)=F_{i}$

$\mathrm{Al}_{2} \mathrm{O}_{3}: \frac{\partial A}{\partial t}=-\frac{M_{A}}{4 M_{C}} k_{\delta}\left(C^{4}\right) A F-\frac{M_{A}}{4 M_{C}} k_{y}\left(C^{3}\right) A-v_{s} \frac{\partial A}{\partial z}, A(0, t)=A_{i}$

$\mathrm{SiO}_{2}: \frac{\partial S}{\partial t}=-\frac{M_{S}}{2 M_{C}} k_{\beta} S\left(C^{2}\right)-v_{s} \frac{\partial S}{\partial z}, S(0, t)=S_{i}$

$\mathrm{CaO}: \frac{\partial C}{\partial t}=-k_{1} \xi-k_{\alpha} C \beta-k_{\beta} S\left(C^{2}\right)-k_{\gamma} C^{3} A-k_{\delta} C^{4} A F-v_{s} \frac{\partial C}{\partial z}, C(0, t)=0$

Fuel (coal/oil): $\frac{\partial C_{F}}{\partial z}=\frac{1}{\rho_{g} v_{g}}\left[\frac{\Psi^{M} C_{1}\left(P M_{a}\right)^{2}}{\rho_{F} M_{O_{2}}\left(R T_{g}\right)^{2}}\right] k_{F} d_{0} C_{F}, C_{F}(L, t)=C_{F}$

Thermodynamic energy balance equations:

Gas: $A_{g} C_{p g} \rho_{g} v_{g}\left(\frac{\partial T g}{\partial z}\right)=\beta_{1}\left(T_{w}-T_{g}\right)+\beta_{2}\left(T_{s}-T_{g}\right)+q_{f}$

$T_{g}(L, t)=T_{g i}$

Solid: $A_{s} C_{p s} \rho_{s} v_{s}\left(\frac{\partial T_{s}}{\partial z}\right)=\beta_{2}\left(T_{g}-T_{s}\right)+\beta_{3}\left(T_{w}-T_{s}\right)-C_{p s} \rho_{s} A_{s}\left(\frac{\partial T s}{\partial t}\right)+A_{s} q_{c}$

$T_{s}(0, T)=T_{s i}$

Kiln wall: $A_{w} C_{p w} \rho_{w}\left(\frac{\partial T w}{\partial t}\right)=\beta_{1}\left(T_{g}-T_{W}\right)+\beta_{3}\left(T_{S}-T_{W}\right)+\beta_{4}\left(T_{a}-T_{W}\right)$ 
Heat of reaction: $q_{c}=\frac{\rho_{s}}{\left(1+A_{i}+F_{i}+S_{i}\right)}\left[-\Delta H_{\xi} k_{1} \xi-\Delta H_{\omega} R_{\omega}-\Delta H_{\beta} k_{\beta} S\left(C^{2}\right)-\Delta H_{\alpha} k_{\alpha} C \beta\right]$ (16)

Flame model: $q_{f}=\frac{G_{f}\left(-\Delta H_{F}\right)}{\left(p_{g} v_{g}\right)}\left[\frac{\Psi^{M} C_{1}\left(P M_{a}\right)^{2}}{\rho_{s} M_{O_{2}}\left(R T_{g}\right)^{2}}\right] k_{F} d_{0} C_{F}$

$d_{0}=1-\frac{k_{F}}{\left(\frac{D_{0} 3}{r_{f}^{2}}\right)+k_{F}}$

$D_{0}=a_{0} T_{g}^{\frac{3}{2}}$

Reaction rate coefficient: $k_{i}=A_{i} \exp \left(\frac{-E_{i}}{R T_{i}}\right)$ $\mathrm{i}=1, \alpha, \beta, \gamma, \delta, \omega$

$k_{F}=\frac{3}{r_{F}} A_{F} \exp \left(\frac{-E_{F}}{R T_{g}}\right)$

Coefficient of heat transfer: $\beta_{1}=r_{1} p\left[f_{1}+1.73 \times 10^{-9}\left(1-h_{0}\right) \varepsilon_{g} \varepsilon_{w}\left(T_{g}^{2}+T_{w}^{2}\right)\left(T_{g}+T_{w}\right)\right]$

$\beta_{2}=2 r_{1} \sin \left(\frac{p}{2}\right)\left[f_{2}+1.73 \times 10^{-9} \varepsilon_{g} \varepsilon_{s}\left(T_{g}^{2}+T_{s}^{2}\right)\left(T_{g}+T_{s}\right)\right]$

$\hat{\mathrm{a}}_{3}=r_{1}(2 Đ-\mathrm{p})\left[\mathrm{f}_{3}+1.73 \times 10^{-9} \mathrm{~h}_{0} \mathrm{a}_{\mathrm{w}} \mathrm{a}_{\mathrm{s}}\left(\mathrm{T}_{\mathrm{w}}{ }^{2}+\mathrm{T}_{\mathrm{s}}^{2}\right)\left(\mathrm{T}_{\mathrm{w}}+\mathrm{T}_{\mathrm{s}}\right)\right]$

$\beta_{4}=2 \Pi f_{4} r_{2}$

$h=1+\frac{2 h_{0} \sin \left(\frac{p}{2}\right)}{2 \Pi-p}$

Area coefficient:

$A_{g}=\frac{r_{1}^{2}}{2}(p-\sin p)$

$A_{s}=\frac{r_{1}^{2}}{2}(2 \Pi-p+\sin p)$

$A_{w}=2 \Pi\left(r_{2}^{2}-r_{1}^{2}\right)$ 